Int. J. Morphol.,

31(1):136-139, 2013.

\title{
Hypoplastic Anterior Tibial Artery Associated with Continuation of Fibular (Peroneal) Artery as Dorsalis Pedis Artery. A Case Report
}

\author{
Arteria Tibial Anterior Hipoplásica Asociada con la Continuación de la \\ Arteria Fibular como Arteria Dorsal del Pié. Un Reporte de Caso
}

Surekha D. Shetty; Satheesha Nayak; Naveen Kumar \& Abhinitha, P.

SHETTY, S. D.; NAYAK, S.; KUMAR, N. \& ABHINITHA, P. Hypoplastic anterior tibial artery associated with continuation of fibular (peroneal) artery as dorsalis pedis artery. A case report. Int. J. Morphol., 31(1):136-139, 2013.

SUMMARY: Arterial variations of distal parts of lower limb are well documented. However, continuation of fibular artery as dorsalis pedis artery is a rare finding. Unusual course and distribution of the anterior tibial artery and fibular artery were observed during routine anatomical dissection of the right lower limb of an approximately 40-year-old male cadaver. The arteries of the crural region arose from the popliteal artery, as usual. However the anterior tibial artery was hypoplastic. The fibular artery was larger than usual and crossed the lowest portion of the interosseous membrane and continued as dorsalis pedis artery. Posterior tibial artery had a normal course and distally divided into medial and lateral plantar arteries. The awareness of these variations is important to vascular surgeons while performing arterial reconstructions in femorodistal bypass graft procedures, and also to orthopaedic surgeons during surgical clubfoot release.

KEY WORDS: Anatomical variaton; Anterior tibial artery; Peroneal artery; Fibular artery; Dorsalis pedis artery.

\section{INTRODUCTION}

Knowledge of anatomical variations in the branching pattern of the popliteal artery is important because damage of its branches can be limb-threatening. Normally, the popliteal artery is the continuation of the femoral artery. It traverses the popliteal fossa and it descends obliquely to the distal border of the popliteal muscle, where it divides into the anterior and posterior tibial arteries. The anterior tibial artery passes in front of the ankle to the dorsum of the foot as the arteria dorsalis pedis. The posterior tibial artery divides into the medial and lateral plantar arteries under abductor hallucis muscle. The peroneal artery arises about $2.5 \mathrm{~cm}$ distal to the popliteus muscle from posterior tibial artery. Reaching the inferior tibiofibular syndesmosis, it divides into the calcaneal branches. Its perforating branch traverses the interosseous membrane about $5 \mathrm{~cm}$ proximal to the lateral malleolus to enter the extensor compartment, where it anastomoses with the anterior lateral malleolar artery. Sometimes this arrangement can be different, may be because of developmental diversity.

\section{CASE REPORT}

During regular dissections for undergraduate medical students at Melaka Manipal Medical College (Manipal Campus) we found arterial variations in a formalin embalmed male cadaver aged approximately 40 years. The variations found were in the right lower limb and were unilateral. The anterior tibial artery was hypoplastic and measured only $1.6 \mathrm{~mm}$ in diameter (Fig. 1 ). It commenced at the lower border of the popliteus muscle and crossed forward between the two heads of the tibialis posterior muscle. The artery then passed through the space above the upper border of the interosseous membrane and descended on the anterior surface of the latter, where it ended above the ankle-joint. Posterior tibial artery had a normal course and distally divided into medial and lateral plantar arteries. The peroneal artery was larger than usual (Fig. 2) and crossed the lowest portion of the interosseous membrane and continued as dorsalis pedis artery (Fig. 3). 


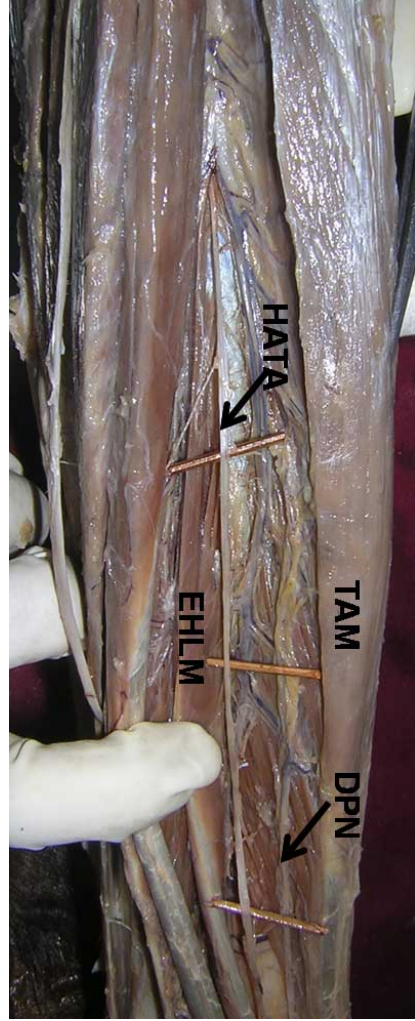

Fig 1. Dissection of the anterior compartment of the right lower leg. TAM. Tibialis anterior muscle; EHLM. Extensor hallucis longus muscle; HATA. Hypoplastic anterior tibial artey, DPN - deep fibular nerve.

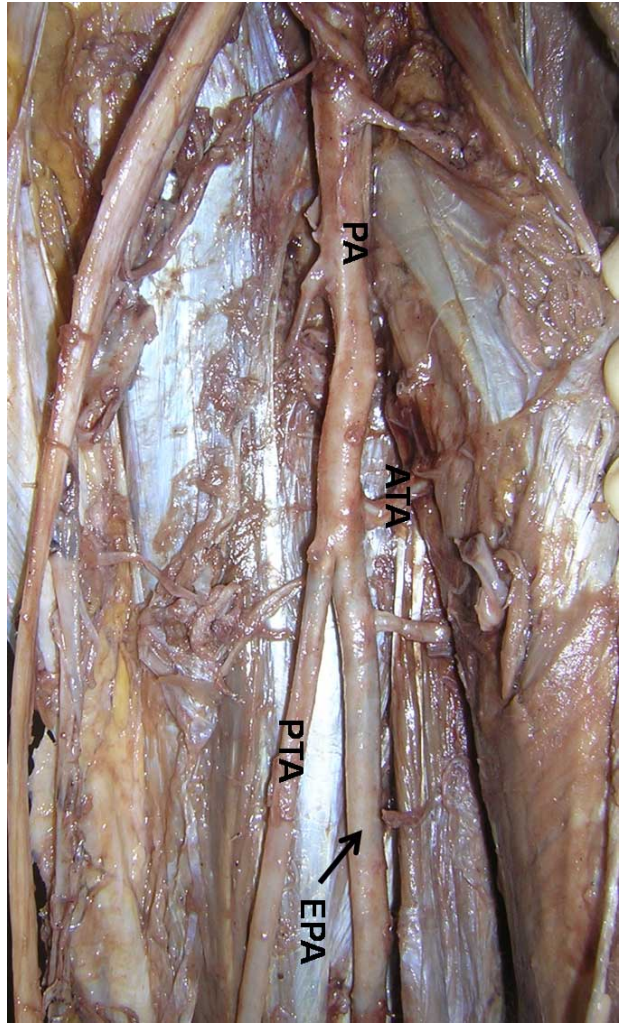

Fig 2. Dissection of the posterior compartment of the right leg showing the main arteries. PA. Popliteal artery; ATA. Anterior tibial artery; PTA. Posterior tibial artery; EPA. Enlarged fibular artery.

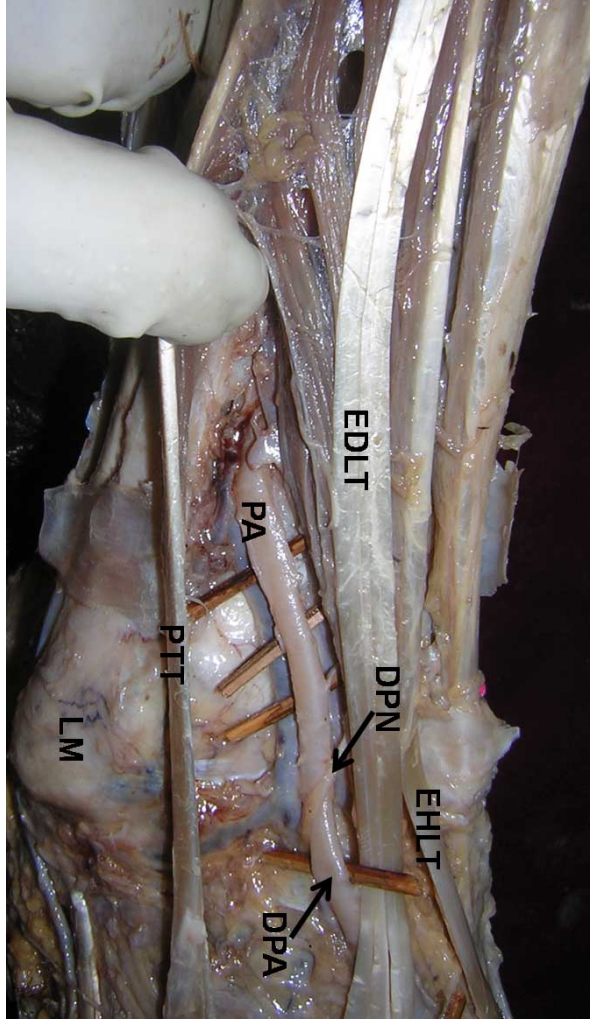

Fig 3. Dissection of the lateral side of the right ankle showing the continuation of fibular artery as the dorsalis pedis artery. PA. Fibular artery; DPA. Dorsalis pedis artery; DPN. Deep fibular nerve; EDLT. Extensor digitorum longus tendon; EHLT. Extensor hallucis longus tendon; PTT. Fibular tertius tendon; LM. Lateral malleolus.

\section{DISCUSSION}

The awareness of the popliteal arterial variants is important for those performing surgical or percutaneous vascular reconstruction in the lower limb. Distal popliteal arterial variations may influence the success of femorodistal popliteal and tibial arterial reconstructions (Kim et al., 1989). The anterior tibial artery is really an acceptable run-off vessel in femorotibial graft. The luminal diameter of the anterior tibial artery is the most important determinant of the patency rate in anterior femorotibial graft (Plecha et al., 1993). Some researchers have shown an association between the absence of the anterior tibial artery and bony malformation of the lower limbs. Kutoglu et al., (2003) have reported a case of fibular artery variation. Jiji et al., (2008) have reported hypoplastic posterior tibial artery and the enlarged fibular artery supplying the posterior crural region. Unusual course and branching pattern of the tibial arteries and their clinical complications has been reported by Atanasova et al. (2011).
Senior (1919) has explained the abnormal branching patterns of the popliteal artery as result of arrest of normal development of limb vessels. The lower limb vessels arise from two sources: the primary limb bud artery (axial or sciatic artery, a branch of the umbilical artery) and the femoral artery. The popliteal and fibular arteries arise from the axial artery, whereas the anterior tibial and posterior tibial arteries are derived from the femoral system. Being the derivative of the axial artery, the fibular artery is constant and true absence of it has never been reported (Hollinshead, 1969). Variability in the crural arteries depends on both the regression of the sciatic artery and also on the persistence of its junction with the primary femoral artery in the popliteal region (Szpinda, 2006).

The fibular artery normally terminates into small branches that communicate with anterior and posterior tibial 
arteries at the level of the ankle joint. In some cases the proximal segments of the anterior and posterior tibial arteries are congenitally absent or hypoplastic, the respective branch of the fibular artery directly supplies their distal distribution areas. Thus it has been reported that the arterial variations mentioned above might influence the success of femorodistal popliteal and tibial arterial reconstructions. When the posterior tibial artery is hypoplastic or aplastic and nutrition of the foot is supplied by perforating branches of the fibular artery, harvesting the fibula together with fibular artery may endanger the nutrition of the foot (Lippert \& Papst, 1985; Kym et al.). Rarely, a hypoplastic anterior tibial artery might be added to this picture. In this situation, surgeons carefully evaluate the surgical approach. In the present case, the posterior tibal artery was of normal size, but anterior tibial artery was hypoplastic. The fibular artery was larger than usual and crossed the lowest portion of the interosseous membrane and continued as dorsalis pedis artery.

In a study by Vijayalakshmi et al., (2011) the dorsalis pedis artery was found to have a normal course and branching pattern in $56 \%$, variation in origin in $8 \%$, variation in branching pattern in $16 \%$, absence of the artery in $2 \%$ of the specimens studied. A case of combined variation of the arteries and the nerve in a leg has been reported by Kurtoglu \& Uluutku (1999). The arterial anatomy of the lower limb is fairly constant. Amith et al., (2010) have found high bifurcation of popliteal artery in $4 \%$, high bifurcation of popliteal artery with fibular artery arising from anterior tibial artery $2 \%$, absent posterior tibial artery in $1-5 \%$, hypoplasia or aplasia of anterior tibial artery with resultant absence of doralis pedis pulse in $4-12 \%$, anomalous location of dorsalis pedis artery in $8 \%$ cases. In present case the right dorsalis pedis artery was replaced by the perforating branch of the fibular artery. Similar anomalies were described unilaterally by Ali \& Mohajir (1996) and bilaterally by Tuncel et al. (1994).

Rodríguez (1993) described the coexistence of campomelic syndrome with marked deficiency of the anterior tibial artery. Hootinick et al., (1984) and Levinsohn et al., (1991) also presented the absence of the anterior tibial artery in patients with severe bony malformations of leg such as clubfoot, deficiency of the calf bone, tibial aplasia, metatarsal absence, ectrodactyly and diplodia. Popliteal arterial variants and the normative data for the anterior tibial artery are important for vascular surgery below the knee.

SHETTY, S. D.; NAYAK, S.; KUMAR, N. \& ABHINITHA, P. Arteria tibial anterior hipoplásica asociada con la continuación de la arteria fibular como arteria dorsal del pie. Un reporte de caso. Int. J. Morphol., 31(1):136-139, 2013.

RESUMEN: Las variaciones arteriales de las partes distales de los miembros inferiores están bien documentados. Sin embargo, la continuación de la arteria fibular como arteria dorsal del pie es un hallazgo raro. El curso y distribución inusual de la arteria tibial anterior y la arteria fibular se observaron durante la disección anatómica de rutina en el miembro inferior derecho del cadáver de un hombre de aproximadamente 40 años de edad. Las arterias de la región crural se originaron desde la arteria poplítea como es usual. Sin embargo, la arteria tibial anterior era hipoplásica. La arteria fibular era más grande de lo habitual, cruzó la porción más baja de la membrana interósea y se mantuvo como la arteria dorsal del pie. La arteria tibial posterior tuvo un curso normal; distalmente se dividió en las arterias plantares medial y lateral. El conocimiento de estas variaciones es importante para los cirujanos vasculares al realizar reconstrucciones arteriales en procedimientos de injerto de bypass femorodistal, y también para los cirujanos ortopédicos durante la liberación quirúrgica del pie zambo.

PALABRAS CLAVE: Variación anatómica; Arteria tibial anterior; Arteria fibular; Arteria dorsal del pie.

\section{REFERENCES}

Ali, M. W. \& Mohajir, A. M. Dorsalis pedis artery: variations and clinical significance. J. Indian Med. Assoc., 94(11):417-8, 1996.

Amit, N. D.; Gupta, P. K. \& Manjeet, S. Digital subtraction angiography: problem solving tool in decision making in equivocal cases of polytrauma. J. Optoelectron. Biomed. Mater., 2(4):245-8, 2010 .

Atanasova, M.; Georgiev, G. P. \& Jelev, L. Intriguing variations of the tibial arteries and their clinical implications. Int. J. Anat. Var., 4:45-6, 2011
Hollinshead, W. H. Anatomy for surgeons. New York, Harper \& Row, 1969. p.807.

Hootnick, D. R.; Packard, D. S. Jr.; Levinsohn, E. M.; Lebowitz, M. R. \& Lubicky, J. P. The anatomy of a congenitally short limb with clubfoot and ectrodactyly. Teratology, 29(2):155-64, 1984.

Jiji, P. J.; D’Costa, S.; Nayak, S. R.; Prabhu, L. V.; Pai, M. M.; Vadgaonkar, R.; et al. Hypoplastic posterior tibial artery and the enlarged peroneal artery supplying the posterior crural region: a rare variation. J. Vasc. Bras., 7(3):272-4, 2008. 
Kim, D.; Orron, D. E. \& Skillman, J. J. Surgical significance of popliteal arterial variants. A unified angiographic classification. Ann. Surg., 210(6):776-81, 1989.

Kurtoglu, Z. \& Uluutku, M. H. A Combined Variation of the Arteries and The Nerve in a Leg. Turk. J. Med. Sci., 29:723-7, 1999.

Kutoglu, K.; Ulucam, E. \& Mesut, R. A case of fibular artery variation. Trakia J. Sci., 1(3):53-5, 2003.

Levinsohn, E. M.; Hootnick, D. R. \& Packard, D. S. Jr. Consistent arterial abnormalities associated with a variety of congenital malformations of the human lower limb. Invest. Radiol., 26(4):364-73, 1991.

Lippert, H. \& Papst, R. Arterial variations in man: classification and frequency. München, J.F. Bergmann Verlag, 1985. pp.604.

Plecha, E. J.; Seabrook, G. R.; Bandyk, D. F. \& Towne, J. B. Determinants of successful peroneal artery bypass. J. Vasc. Surg., 17(1):97-105; discussion 105-6, 1993.

Rodríguez, J. I. Vascular anomalies in campomelic syndrome. Am. J. Med. Genet., 46(2):185-92, 1993.

Senior, H. D. The development of the arteries of the human lower extremity. Am. J. Anat., 25(1):54-95, 1919.

Szpinda, M. An angiographic study of the anterior tibial artery in patients with aortoiliac occlusive disease. Folia Morphol. (Warsz), 65(2):126-31, 2006.
Tuncel, M.; Maral, T.; Celik, H. \& Tascioglu, B. A case of bilateral anomalous origin for dorsalis pedis arteries (anomalous dorsalis pedis arteries). Surg. Radiol. Anat., 16(3):319-23, 1994.

Vijayalakshmi, S.; Raghunath, G. \& Shenoy, V. Anatomical study of dorsalis pedis artery and its clinical correlations. J. Clin. Diag. Res., 5(2):287-90, 2011.

Correspondence to:

Dr. Satheesha Nayak B.

Professor and Head, Department of Anatomy Melaka Manipal Medical College (Manipal Campus) International Centre for Health Sciences

Madhav Nagar Manipal

Udupi District, Karnataka State, 576104

INDIA

Telephone: +91820 2922519

Fax: $\quad+918202571905$

Email: nayaksathish@yahoo.com

Received: 16-12-2011

Accepted: 15-12-2012 